\title{
Enteritis associated with Lawsonia intracellularis and porcine circovirus type 2 infection in wild boars in Southern Brazil
}

\author{
Enterite associada com infecção por Lawsonia intracellularis e circovírus suíno tipo 2 em um \\ rebanho de javalis no Sul do Brasil
}

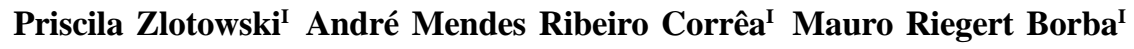 \\ Cláudio Estêvão Farias Cruz ${ }^{\mathrm{I}}$ David Driemeier $^{{ }^{*}}$
}

\begin{abstract}
In a commercial herd of 1250 wild boars, 56 animals were affected by anorexia, diarrhea, and wasting. Enlargement of mesenteric lymph nodes, thickening of ileal wall, and a white-yellowish ileal content were observed in two of the four animals necropsied. Microscopically, ileal crypts showed epithelial hyperplasia, moderate decrease in goblet cell density, lymphohistiocytic infiltrate in the lamina propria, and moderate depletion with histiocytic infiltrate in Peyer's patches. Curved rod-shaped organisms within the apical cytoplasm of enterocytes were observed in both Warthin-Starry and Lawsonia intracellularis-immunostained sections. PCV2 antigen was observed in ileal Peyer's patches of 3 wild pigs. Trichuris suis nematodes were found in the cecum of the four wild pigs. This report describes clinicopathological findings in cases of enteritis associated with Lawsonia intracellularis and PCV2 infection in a commercial herd of wild boars.
\end{abstract}

Key words: wild boars,Sus scrofa, Lawsonia intracellularis, PCV2.

\section{RESUMO}

Neste trabalho, são relatados os achados clínicopatológicos de casos de enterite associados com infecção por Lawsonia intracellularis e PCV2 em um rebanho comercial com 1250 javalis, sendo que 56 foram afetados por anorexia, diarréia e emagrecimento progressivo. Em dois dos quatro animais necropsiados, foi observado aumento de linfonodos mesentéricos, espessamento da parede do íleo e conteúdo branco-amarelado no íleo. Microscopicamente, as criptas do íleo apresentavam hiperplasia epitelial, decréscimo moderado na densidade de células caliciformes, infiltrado linfohistiocitário na lâmina própria e depleção moderada das placas de Peyer com infiltrado histiocitário. Bastonetes curvos no ápice citoplasmático dos enterócitos foram observados em preparações coradas com Warthin-Starry e pela imunoistoquímica contra Lawsonia intracellularis. Antígeno de PCV2 foi observado nas placas de Peyer do íleo de três animais e nematódeos Trichuris suis estavam presentes no ceco dos quatro javalis necropsiados.

Palavras-chave: javalis, Sus scrofa, Lawsonia intracellularis, PCV2.

\section{INTRODUCTION}

Proliferative enteropathy (PE), a worldwide condition caused by Lawsonia intracellularis infection has been described in a wide range of species of animals, but especially in swine (COOPER et al., 1997; LAWSON \& GEBHART, 2000). Anorexia, wasting and diarrhea are usually present in animals with this condition. The porcine proliferative enteropathy (PPE) complex includes a number of clinicopathological manifestations (ROWLAND \& LAWSON, 1992) in which the presence of curved rod-shaped bacteria within the apical cytoplasm of the enterocytes from hyperplastic ileal crypts is the most characteristic lesion (McORIST et al., 1992). Diagnosis has been based on histopathology, Warthin-Starry staining, serology, polymerase chain reaction and immunohistochemistry (LAWSON \& GEBHART, 2000). Post weaning multisystemic wasting syndrome (PMWS) associated with PCV2 infection is the major disease affecting commercial herds of swine worldwide. PCV2 has been associated with a number of disease syndromes and the mainly reported clinical signs were wasting, unthriftiness, pallor, icterus, respiratory distress and

'Departamento de Patologia Clinica Veterinária, Universidade Federal do Rio Grande do Sul (UFRGS), Porto Alegre, RS, Brasil. Av. Bento Gonçalves 9090, 91540-000, Porto Alegre, RS, Brasil. E-mail: davetpat@ufrgs.br. *Autor para correspondência. 
diarrhea. PCV2 infection is characterized microscopically by depletion and histiocytic replacement of follicles in lymphoid tissues; giant cells and cytoplasmic inclusion bodies in macrophages are also characteristic of PCV2 associated diseases. Diagnosis of a PCV2 infection includes microscopic lesions and demonstration of the virus associated with characteristic lesions (OPRIESSNIG et al., 2007).

PCV2 was associated with PE in swine commercial herds (JENSEN et al., 2006). Co-infection with other pathogens is commonly reported in PMWS affected pigs and it is suggested that a secondary immunodeficiency caused by the virus predisposes those co-infections (SEGALÉS et al., 2004). Although this synergy was not observed with $\boldsymbol{L}$. intracellularis, a possible antagonistic relationship represented by a number lower than expected of dual infection was related (JENSEN et al., 2006). Granulomatous enteritis associated with $\mathbf{L}$. intracellularis and PCV2 infection was described in one commercial wild boar (SEGALÉS et al., 2001).

Wild boars have been demonstrated as susceptible to many diseases that usually affect domestic pigs (PÉREZ et al., 1998; 1999; SCHULZE et al., 2004) and the potential risk of transmission between wild and domestic pigs has been highlighted. Traditionally wild boars were found as free living animals. This change in the production system may lead to similar clinical disease presentation in wild boars and conventional pigs (SEGALÉS et al., 2001). In Brazil, the wild boar population is almost exclusively restricted to commercial herds, based in semi-intensive and intensive production system. This communication describes an outbreak of enteritis associated with $\boldsymbol{L}$. intracellularis and PCV2 infection in a commercial herd of wild boar.

\section{MATERIAL AND METHODS}

The disease occurred in a farm located in the state of Rio Grande do Sul, Brazil. The herd was composed of 1250 wild pigs, of which 56 showed anorexia, diarrhea and wasting. PMWS was previously diagnosed in this herd. Most of the affected animals were in the postweaning group, with an average age of 4-mo. Four animals suffering with persistent diarrhea were euthanized. Segments of mesenteric lymph nodes, ileum, cecum, colon, lungs, tonsils, hearth, kidney, stomach, spleen and central nervous system were fixed on $10 \%$ buffered formalin, routinely processed for histology, and stained with haematoxylin and eosin. Samples of small and large intestine were submitted for bacteriology. Warthin-Starry staining was performed in ileam samples. Immunohistochemical probing with polyclonal antisera to L. intracellularis (GUEDES \& GEBHART, 2003) counterstained with alcian blue and Mayer's hematoxylin in a similar combination of staining methods as that described previously (DRIEMEIER et al., 2002) was performed in ileal samples. Immunostaining using polyclonal anti-PCV2 (SORDEN et al., 1999) was applied to lymph nodes, small and large intestines, lungs and kidney from the four animals.

\section{RESULTS}

Because of the lack of response to supportive and antimicrobial therapy and continuous deteriorating conditions, 4 animals were euthanized and necropsied. The main gross lesions were enlargement of mesenteric lymph nodes and thickening of the wall of the ileum. Ileal loops were filled with white-yellowish contents that included fluids, clots or flakes (Figure 1). These changes were observed in two animals. Nematodes subsequently identified as Trichuris suis were observed in the cecum from all four animals.

The main histological findings were in the ileal crypts and included epithelial hyperplasia, moderately decreasednumber of goblet cells, mitotic figures (2/4), histiocytic and neutrophilic infiltrates in the mucosa (2/4) and depletion of Peyer's patches associated with histiocytic infiltrate (4/4). Ileal crypts showed dilatation and contained inflammatory cells mainly neutrophils and cellular debris (2/4). Moderate lymphohistiocytic infiltrate was noted in the large intestine (4/4). Moderated lymphoid depletion was observed in the lymph nodes and spleens of all animals.

Warthin-Starry stained sections of ileum revealed curved rod-shaped organisms in the cytoplasm of the crypt enterocytes (2/4). Immunohistochemical probing with polyclonal antisera to $\boldsymbol{L}$. intracellularis (GUEDES \& GEBHART, 2003) counterstained with alcian blue and Mayer's hematoxylin demonstrated both the bacteria and the decreased density of goblet cells in the affected crypts (Figure 2). Immunostaining with anti-PCV2 was positive in Peyer's patches (3/4). Pathogenic bacteria was not detected in cultures from intestinal samples. A therapy based on tiamulin ${ }^{\mathrm{a}}$ and ivermectin ${ }^{\mathrm{b}}$ was implemented for the remaining animals and good recovering rates were obtained.

\section{DISCUSSION}

The clinicopathological findings observed here were consistent with those reported in domestic pigs suffering from porcine intestinal adenomatosis 


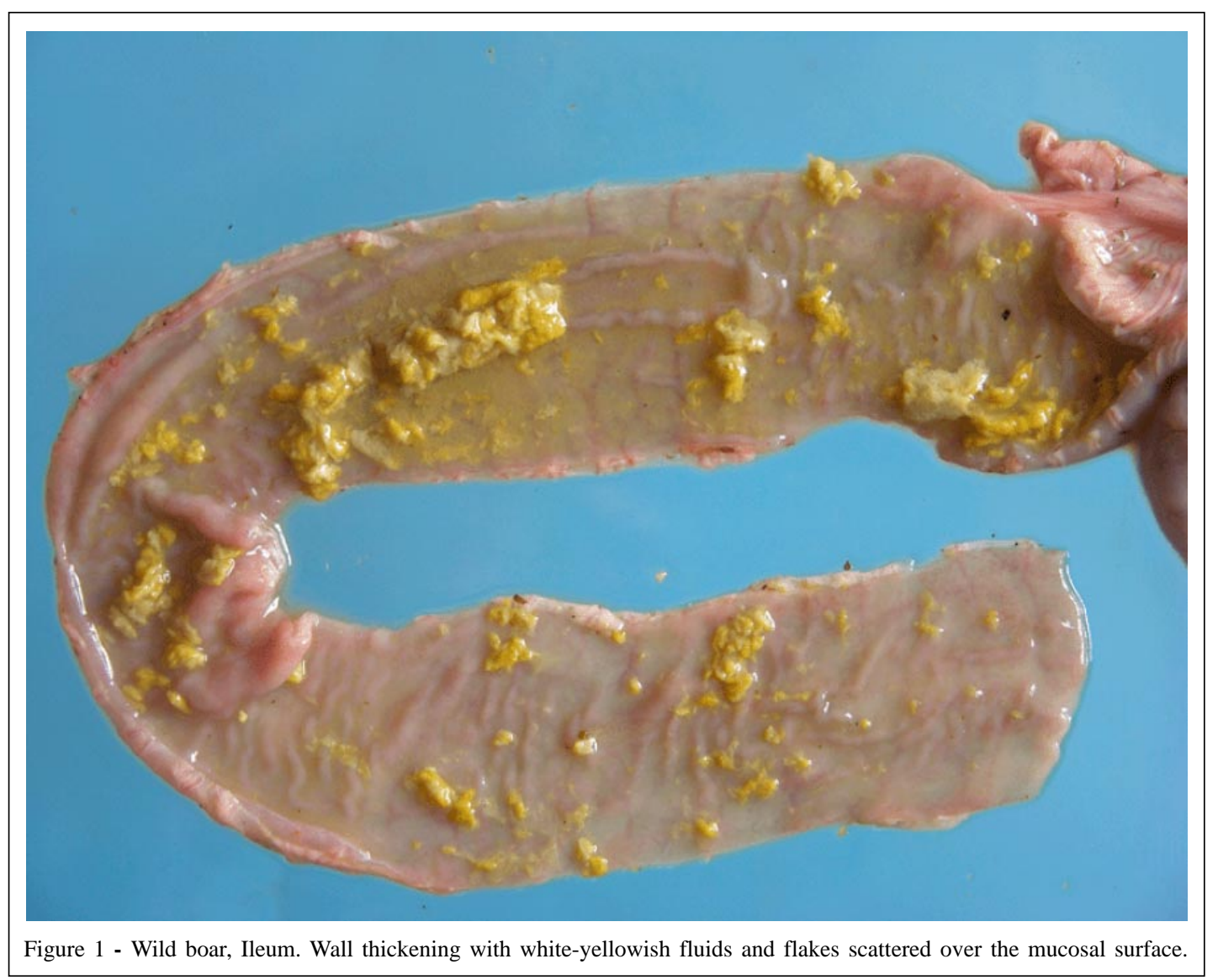

(LAWSON \& GEBHART, 2000) due to $\boldsymbol{L}$. intracellularis infection. Additionally, some lesions were similar to that reported in an outbreak of PCV2 infection in wild boars (CORRÊA et al., 2006).

Simultaneous co-infection with $\boldsymbol{L}$. intracellularis and Trichuris suis has previously been described in swine and wild boars (PEARCE, 1999; SEGALÉS et al., 2001). However, there has been no report on the goblet cell dynamics in wild boars infected with $\boldsymbol{L}$. intracellularis. Nematode infection in swine has been associated with hyperplasia of goblet cells (KHAN et al., 2001). The marked paucity of goblet cells usually seen in PE in domestic pigs was not observed in these wild boars. It is possible that this typical decreasing of the goblet cell mucin stores had partialy been compensated by an increasing in this cell population attributed to the nematode infection.

We were not able to determine if the strains of PCV2 and $\boldsymbol{L}$. intracellularis found here were the same that have been affecting domestic and wild pigs in southern Brazil, but similarities between these strains have been reported (TOMANOVÁ et al., 2002; SCHULZE et al., 2004). Probably, risk factors linked to intensive farming as those reported in domestic pigs
(PEARCE, 1999; McORIST et al., 1999) may have predisposed these animals to $\boldsymbol{L}$. intracellularis infection, since wild boars are mostly free living animals.

The main histological lesions seen here characterized these cases as intestinal adenomatosis; they were not related with any necrotic changes or hemorrhagic enteropathy observed in the PPE complex of pigs, since necrosis was not observed in the intestinal mucosa. Enteritis cases due to PE and PCV2 infection may share several similar macroscopic and microscopic lesions in pigs. Severe coagulative necrosis of the intestinal mucosa may be found in enteritis due to PCV2 infection and can lead to a gross misdiagnosis of PE (JENSEN et al., 2006). In the present study, one boar had diarrhea and also PCV2 antigen in Peyer's patches, but without any macroscopic changes suggestive of PE. This may suggest that a differential diagnosis between PCV2 enteritis and $\boldsymbol{L}$. intracellularis infection must be made also in wild boars raised in commercial herds showing diarrhea as demonstrated for swine. Even though most of the world's populations of wild boars are free ranging, there is a growing tendency to commercialization and 


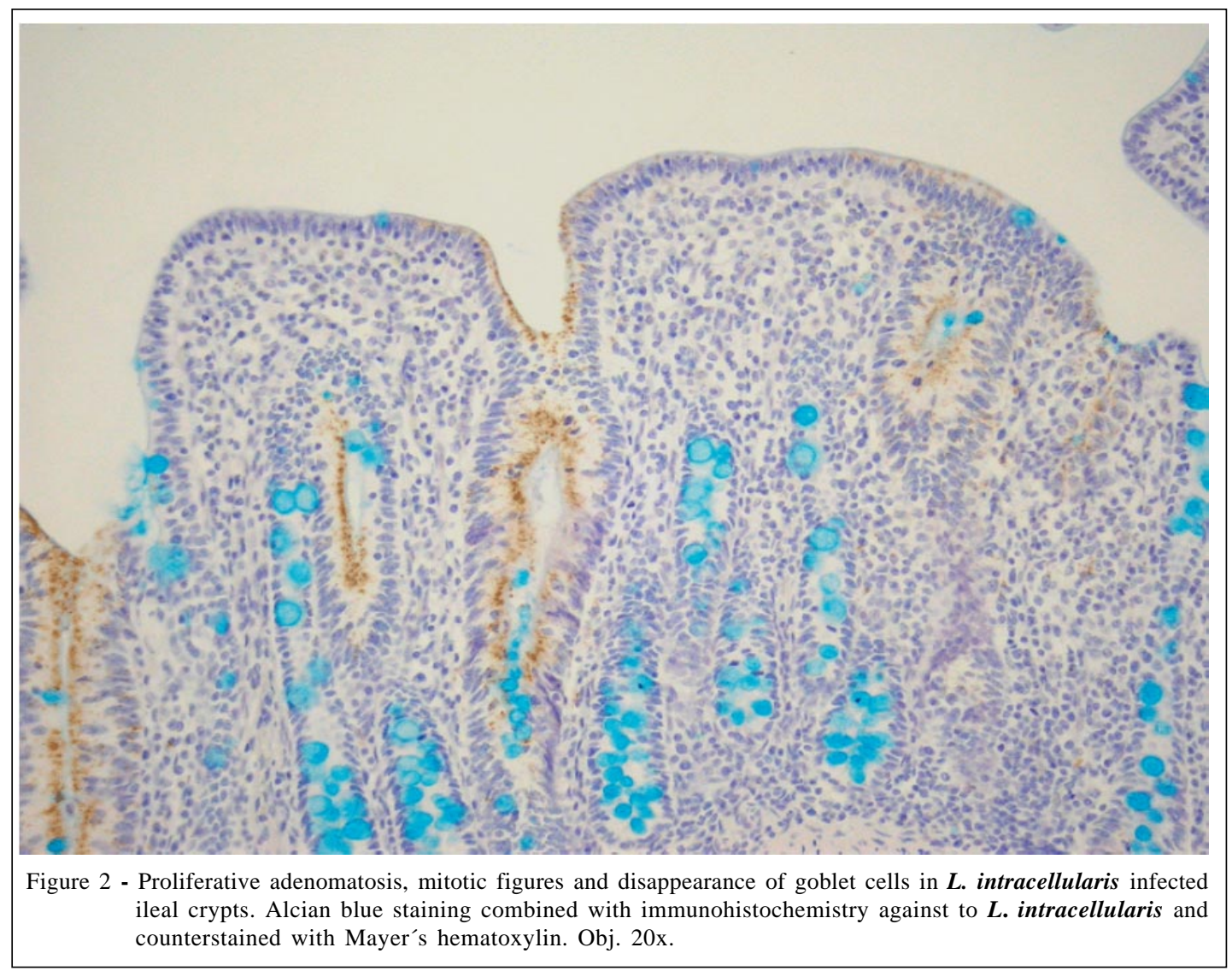

understanding clinical disease and interactions of disease agents is important.

\section{ACKNOWLEDGEMENTS}

Authors are grateful to Prof. PhD. Roberto M. C. Guedes from UFMG for providing the Lawsonia intracellularis antibody, to Prof. PhD. José Felipe Amato from UFRGS for the identification of the parasites, and to CNPq and CAPES for financial support.

\section{SOURCES AND MANUFACTURERS}

aTiamutin, Novartis Animal Health

${ }^{\text {b} I v o m e c ~ s w i n e, ~ M e r i a l ~}$

\section{REFERENCES}

CORRÊA, A.M.R. et al. Postweaning multisystemic wasting syndrome in farmed wild boars (Sus scrofa) in Rio Grande do Sul. Pesquisa Veterinária Brasileira. Rio de Janeiro, v.26, p.154-156, 2006.

COOPER, D.M. et al. Comparison of the 16s ribosomal DNA sequences from the intracellular agents of proliferative enteritis in a hamster, deer, and ostrich with the sequence of a porcine isolate of Lawsonia intracellularis. Internal Journal Systematic Bacteriology, Washington DC, v.47, p.635-639, 1997.
DRIEMEIER, D. et al. Silver staining combined with alcian blue and hematoxylin-eosin for the detection of Lawsonia intracellularis in swine proliferative enteropathy. Acta Histochemica, Jena, v.104, p.285-287, 2002.

GUEDES, R.M.; GEBHART C.J. Preparation and characterization of polyclonal and monoclonal antibodies against Lawsonia intracellularis. Journal Veterinary Diagnostic Investigation, Columbia, v.15, p.438-446, 2003.

JENSEN, T.K. et al. Distinction between Porcine Circovirus Type 2 enteritis and Porcine proliferative enteropathy caused by Lawsonia intracellularis. Journal Comparative Pathology, Liverpool, v.136, p.176-182, 2006.

KHAN, W.I. et al. Stat6 dependent goblet cell hyperplasia during intestinal nematode infection. Parasite Immunology, Oxford, v.23, p.39-42, 2001.

LAWSON, G.H.K.; GEBHART, C.J. Proliferative enteropathy. Journal Comparative Pathology, Liverpool, v.122, p.77100, 2000.

McORIST, S. et al. Immunocytological responses in porcine proliferative enteropathies. Infection and Immunity, Washington DC, v.60, p.4184-4191, 1992.

McORIST, S. et al. Monitored control programme for proliferative enteropathy on British pig farms. Veterinary Record, London, v.144, p.202-204, 1999. 
OPRIESSNIG, T. et al. Porcine circovirus type 2-associated disease: Update on current terminology, clinical manifestations, pathogenesis, diagnosis, and intervention strategies. Journal Veterinary Diagnostic Investigation, Columbia, v.19, p.591615, 2007.

PEARCE, G.P. Interactions between dietary fiber, endoparasites and Lawsonia intracellularis bacteria in growerfinisher pigs. Veterinary Parasitology, Amsterdam, v.87, p.51-61, 1999.

PÉREZ, J. et al. Serological and immunohistochemical study of African swine fever in wild boar in Spain. Veterinary Record, London, v.143, p.136-139, 1998.

PÉREZ, J. et al. Outbreak of salmonellosis in farmed European wild boars (Sus scrofa ferus). Veterinary Record, London, v.145, p.464-465, 1999.

ROWLAND, A.C.; LAWSON, G.H.K. Porcine proliferative enteropathies. In: LEMAN, A.D. et al. Diseases of swine. Iowa: Iowa State University, Chap. p.560-569, 1992.
SEGALÉS, J. et al. Granulomatous enteritis and lymphadenitis in Iberian pigs naturally infected with Lawsonia intracellularis. Veterinary Pathology, Lawrence, v.38, p.343-346, 2001.

SEGALÉS, J. et al. Immunosuppression in postweaning multisystemic wasting syndrome affected pigs. Veterinary Microbiology, Amsterdam, v.98, p.151-158, 2004.

SCHULZE, C. et al. Identification of postweaning multisystemic wasting syndrome in European wild boar (Sus scrofa). Veterinary Record, London, v.154, p.694-696, 2004.

SORDEN, S.D. et al. Development of a polyclonal-antibodybased immunohistochemical method for the detection of type 2 porcine circovirus in formalin-fixed, paraffin-embedded tissue. Journal Veterinary Diagnostic Investigation, Columbia, v.11, p.528-530, 1999.

TOMANOVÁ, K. et al. Detection of Lawsonia intracellularis in wild pigs in the Czech Republic. Veterinary Record, London, v.151,p.765-767, 2002. 